\title{
Büyük Mecmua'da savaş sonrasını konu alan şiir ve nesirler
}

Esat CAN1

\begin{abstract}
APA: Can, E. (2020). Büyük Mecmua'da savaş sonrasını konu alan şiir ve nesirler. RumeliDE Dil ve Edebiyat Araştırmaları Dergisi, (Ö7), 280-297. DOI: 10.29000/rumelide.808704.
\end{abstract}

\section{Öz}

Osmanlı devleti dört yıl süren Birinci Dünya Savaşı'ndan mağlûp çıkar. Savaş sonrası imzalanan Mondros Mütarekesi (30 Ekim 1918), galip devletlerin dayattığı şartları içerir. Türkiye kendini son derece ağır bir savaş sonu ortamı içinde bulur. Ordu dağıtılır, işgaller başlar. Savaş yorgunu halk, aydınlar ve gençlik elem ve ıstırap içindedir. Savaş sonrasında çıkan Büyük Mecmua, bu dönemin önemli fikir ve edebiyat yayınlarından biridir. 6 Mart 1919-25 Aralık 1919 tarihleri arasında on yedi sayı neşredilen mecmuada zamanın tanınmış şair ve yazarlarının yazılarına yer verilir. Çalışmamızda bu eserler, işledikleri fikir ve duygular bakımından incelenecektir.

Anahtar kelimeler: Büyük Мecmua, savaş, işgal, İstanbul, şiir, nesir

\section{Post-war poems and prose in Büyük Mecmua}

\begin{abstract}
The Ottoman Empire was defeated in the World War I. The Armistice of Mudros, signed after the war (30 October 1918), incorporated provisions imposed by the victorious states. Turkey found itself in an extremely acute aftermath of the war. The army had been disbanded; invasions had been starting. The people, the elite and the youth were in agony. Büyük Mecmua, which was started to be published after the war, was one of the most important idea and literature publications of that period. The works of renowned authors and poets of that period were published in this magazine, which had seventeen issues between 6 March 1919 and 25 December 1919. In this article, we are going to examine these works within the scope of the ideas and emotions enshrined in them.
\end{abstract}

Keywords: Büyük Mecmua, war, invasion, İstanbul, poetry, prose

\section{Giriş}

Dört yll süren Birinci Cihan Harbi, Osmanlı Devleti'nin Trablusgarp ve Balkan Savaşları'ndan sonra girdiği üçüncü savaştır. Afrika ve Rumeli'deki toprak kayıplarına rağmen hâlâ geniş bir coğrafyaya sahip olmakla birlikte siyasî, askerî, sınâ̂, özellikle ekonomik ve mâlî bakımdan çeşitli zaaf ve sıkıntıların yanı sıra manevî takatsizlik ve huzursuzluk içinde bulunan (Eroğlu, 1982: 76) imparatorluk, bu harbe giren İtilâf ve İttifak grupları içinde savaşın yükünü taşımaya hazır olmak bakımından gücü ve mukavemeti en az olan devlettir. İmparatorluğun, her şeye rağmen girdiği ve birbirinden pek uzak beş büyük cephede savaştığı harpte, dünya genelinde dokuz milyon insan ölmüş, Türkiye de bu savaşta altı yüz bin şehit vermiş, iki milyonu aşkın askeri ise yaralı veya sakat kalmıştır. (Tansel, 1991: 2) Söz konusu harp, Filistin ve özellikle Çanakkale'deki fevkalade muzafferiyetlere rağmen, Almanya ve Bulgaristan ile birlikte Osmanlı Devleti’nin de aleyhine sonuçlanmış, doğrudan doğruya galiplerin şartlarını içeren Mondros Mütarekesi’nden (30 Ekim 1918) sonra ise Türkiye, devlet

Dr. (Edirne, Türkiye), esatcan418@gmail.com, ORCID ID: 0ooo-00o2-2542-0007 [Makale kayıt tarihi: 11.08.2020kabul tarihi: 20.10.2020; DOI: 10.29000/rumelide.808704] 
ve millet olarak kendini son derece ağır bir savaş sonrası ortamının içinde bulmuştur. Millî gururu rencide eden işgaller, dağıtılan ordu, kapanan meclis, tükenen ekonomi, bu izmihlâl tablosunun başlıca unsurlarıdır. 1911 yılından beri süregelen harpler yüzünden zaten yorgun ve yılgın olan Müslüman halk ile vatansever aydınlar ve gençlik, elem ve ıstırap içindedir. Kısaca, savaşın bittiği gün gelinen noktada Osmanlı İmparatorluğu bir "facia" ile, Türk milleti de bir varlık-yokluk davası ile karşı karşıyadır.

Aydınların ve halkın bu döneme dair fikir ve duyguları, zamanın gazete ve dergilerinde sansürün müsaadesi nispetinde yer bulur. Bunlar içinde, 6 Mart 1919 ile 25 Aralık 1919 tarihleri arasında çıan Büyük Мecmua da dönemin nabzını tutan, gençliğe ve halka moral verme gayretinde olan önemli süreli yayınlardan biridir. Bu çalışmada Büyük Mecmua'da yayımlanan şiir ve nesirlerden savaş sonrasını konu alanlar, işledikleri fikir ve duygular bakımından incelenecektir.

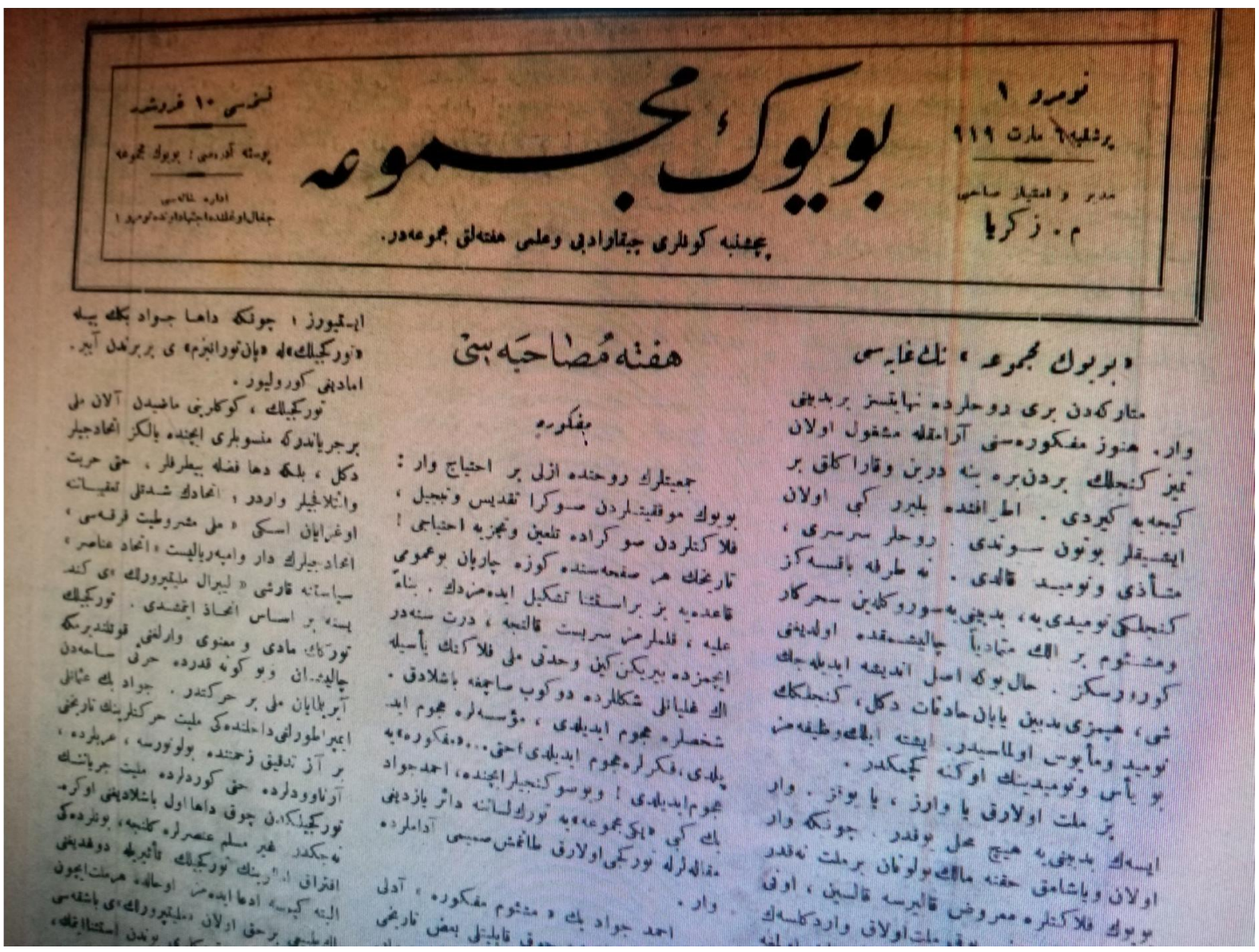

\section{Savaş sonrasını konu alan şiir ve nesirler}

Mütareke'den yaklaşık dört ay sonra 6 Mart 1919'da BüyükMecmua'nın ilk sayısı yayımlanır. Öncelikli gaye, memleketin hali yüzünden ümitsizlik ve karamsarlığa düşen gençliğe rehberlik edip istikamet göstererek onu içinde bulunduğu menfi psikolojiden kurtarmak ve mefkûre sahibi yapmaktır. Mecmuanın çıkarılışamacı, ilk sayıda imzasız olarak neşredilen "Hafta Musahabesi” başlıklı yazıda şöyle açıklanır: 


\begin{abstract}
"Mütareke'den beri ruhlarda nihayetsiz bir bedbinî var. Henüz mefkûresini aramakla meşgul olan temiz gençlik birden bire yine derin ve karanlı geceye girdi. Etrafta belirir gibi olan ışıklar bütün söndü. Ruhlar serseri, müteezzi ve nevmit kaldı. Ne tarafa baksanız gençleri nevmidîye, bedbinîye sürükleyen sihirkâr ve meşum bir elin mütemadiyen çalışmakta olduğunu görürsünüz. Hâlbuki asıl endişe edilecek şey, hepimizi bedbin yapan hadisat değil, gençliğin nevmit ve meyus olmasıdır. İşte, ilk vazifemiz bu yeis ve nevmidînin önüne geçmektir.”2
\end{abstract}

On ay süre ile ve on yedi sayı olarak yayımlanan mecmuanın yazar ve şairleri şu isimlerdir:

Falih Rıfkı, Yusuf Ziya, Köprülüzâde Mehmet Fuat, İsmail Hakkı, Faruk Nafiz, Mehmet Emin, Sabiha Zekeriya, Ömer Seyfettin, Tekin Alp, Halide Edip, M. Zekeriya, Abdullah Cevdet, Tahsin Nahit, Ali Canip, Reşat Nuri, Yahya Kemal, Kâzım Nâmi, Rauf Ahmet, Orhan Seyfi, Rıza Tevfik, Necmettin Sadık, Celâl Derviş, Musa Süreyya, Ruşen Eşref, Kemalettin Kâmi, Münir Tevfik, Hüseyin Ragıp, Ahmet Rasim, Âkil Koyuncu, Halit Fahri.

Sanatkârların ele aldıkları konu veya temlerin şu başlıklar altında incelenmesi mümkündür:

Elem ve Istırap duyguları, dua ve yalvarışlar, gayrimüslimler, ümit ve kurtuluşa inanç, mefkûre, İzmir, İstanbul.3

\title{
1. Elem ve istirap duyguları
}

Savaşın ve Mütareke'nin hemen sonrasında Ekim-Mayıs ayları arasındaki bu beş altı aylık dönem; yorgunluk, yılgınlık, ümitsizlik ve karamsarlı̆̆ın son haddine vardığı bir dönemdir. Sanatkârlar ise bu dönemin psikolojisini en yoğun şekilde yaşayan insanlardır. Bundan dolayı onlar, imparatorluğun ve özellikle de işgale uğrayan şehirlerin hali karşısında hissettikleri derin elem ve ıstırap duygularını eserlerine yansitırlar.

Faruk Nafiz, "Hisarda Akşam” şiirinde güneşin batışı esnasında ufkun kızıllı̆̆ına bakarken vatanın içine düştüğü durum karşısında duyduğu sürekli elemi kalbinin "damla damla" kanaması mecazıyla ifade eder:

\section{"HİSARDA AKŞAM}

Kalbimde akarak damla damla kan

Hisarın üstünde batıyor güneş.

Ufukta belirsiz bir iz birakan

Kocaman bir şehir matemle kardeş.

Yabancı değilken bana bu diyar

Gönlümde vatansız bir genç ye'si var.

Bilmem ki bu akşam ey güzel hisar,

Kararan ruhuma baykuşlar mı eş?

Yüreğim yanarken yeni bozguna

İmzasız. (6 Mart 1919).Büyük Mecmua’nın Gayesi.Büyük Mecmua. (1), 1. İstanbul.

Süleyman Uzkuç, Büyük Mecmua üzerine kapsamlı bir çalışma yapmıştır. İncelediğimiz metinlerin bir kısmı bu tezden alınmıştır: Uzkuç, S. (2005). Büyük Mecmua-Tahlili Fỉhrist- İnceleme-Metin. (Yüksek Lisans Tezi). Selçuk Üniversitesi Sosyal Bilimler Enstitüsü. Konya. 
Gözümde tütüyor ilâhi Tuna...

En sonra sönüyor Türk'ün ruhuna

Senin beş asırdır baktığın güneş!” (Büyük Mecmua, (6), 85)

Matem bütün bir şehri tutmuştur. "Gurub" istiaresi üzerinden ustalıkla sürdürülen metinde akşamın hasıl ettiği hüzün, şairde aynı zamanda bir bitiş ve tükeniş hissini doğurur; sanatkâr, akşam vaktinin ilerleyen karanlığını kendi ruhunun kararması olarak hisseder. Kaybedilen onca topraktan sonra son kalan yurt parçasının da çeşitli köşelerinin işgale uğraması karşısında genç şair, kendini âdeta "vatansız" hisseder.Aynı saatlerde Hisar'da öten baykuşlar, onda kötü ve ürkütücü hadiselerin çağrışımını yaptırırlar. Şairin yüreğini yakan bu savaş ve onun getirdiği hezimet, bizim ilk mağlûbiyetimiz de değildir. "Yeni bozgun" tamlaması, okuyucuya önceki bozgunları, 93 Harbini, Trablusgarp ve Balkan Savaşları'nın acı sonuçlarını çağrıştırır. Beş yüzyıl boyunca kudret ve heybetin sembolü olan Tuna, şimdi hem mesafe olarak hem de tasavvur olarak uzaklarda kalmıştır. Kan, batmak, matem, yeis, kararmak, baykuş, yürek yanması, sönmek kelimelerinin, elem ve ıstırap duygularının yoğunlaştırılmasına yaptığı katkı, şiirin etkileyiciliğini arttırır. Buraya Faruk Nafiz’in Millî Edebiyat Türkçesinin iyi bir örneğini vermesinin yanı sıra tabii ve canlı söyleyişini de eklemek lâzımdır.

Yusuf Ziya, "Bir sarışın sonbahar akşamıydı bu" diye başlayan "Guruba Doğru” şiirinde elem ve ıstırap duygularını, Faruk Nafiz gibi, "gurub” kurgusu üzerinden ve bir eski askerin, güneşin batışı vaktinde köylülerine savaşı "mersiye gibi” hikâye etmesi şeklinde mısralaştırır:

“...

Zati birbirine diyordu herkes

Beyhude, zaferden ümidini kes!

İşte son felaket geldi diyorduk!

Binlerce arkadaş kaybediyorduk,

Gittikçe yı̆̆ıldı düşman askeri,

Cephe ağır ağır çekildi geri!

Nihayet bir akşam bozgun verildi:

Ufukta sönerken güneşin nuru,

Ordu geçip gitti guruba doğru!” (Büyük Мecmua, 1919: (7), 103)

Yusuf Ziya'nın söyleyişi, Faruk Nafiz’inki kadar güçlü ve etkileyici olmamakla birlikte, o da güneşin batışıyla imparatorluğun "batış" arasında benzerlik ilgisi kurar, "son felaket" ve "bozgun" nitelemeleri, Faruk Nafiz'in tanımlamalarıyla benzeşir. Şiir, anlatıcı köylünün, ordunun "guruba doğru” geçip gittiğini söylemesiyle,yani gurup vaktinde anlatılangeçmiş zamana ait bir gurup hikâyesiyle sona erer. Gurup tasviri içinde gurup hikâyesi, anlatımdaki sönüklüğe rağmen, şiirin kurgusu bakımından orijinal sayılmak gerekir. Güneş için kullanılan sönmek fiili ise bu son noktada okuyucuya mağlûp ordunun tükenişini ve bitişini hissettirir.

Yusuf Ziya, "Bahar" şiirinde baharın gelmiş olmasına rağmen tabiatta bahar coşkusundan eser bulunmadığını ifade eder: 
"Bahar oldu diyorlar... Niçin bu dağlar ıssız?

Niçin elâ gözlerin bulutlu ey güzel kız?

Bahçeler boş, ağaçlar niçin böyle sapsarı?

Korkuluklar bekliyor ekinsiz tarlaları!

Tabiatın kalbinde gizli bir hıçkırık var,

Tıpkı mezar taşları gibi şu dik kayalar!

$\cdots$

Akşam, güneş bir mecruh asker gibi bakıyor.

Sanki bozgun bir ordu ufukları yakıyor.

$\ldots$

Artık eski günlerin farkı yok efsaneden,

Neden benizler uçuk, kirpikler yaşlı, neden?” (Büyük Mecmua, 1919: (6), 85)

Tabiatı derin elem duygusunun arkasından seyreden şair, mevsim ilkbahar olmasına rağmen, onun hiçbir güzelliğini idrak edemez. Kendi matem psikolojisini tabiata ve ondaki varlıklara yansıtıp teşhis ve teşbihleryaparak şiirinin örgüsünü sürdürür. "Tabiatın kalbinde gizli bir hıçkırık” söyleyişi,Cenap Şahabettin'in şiirlerini hatırlatır. Fakat buradaki duygusallık, bir Servet-i Fünûn santimantalitesi değil,elden giden bir vatana ve istiklâle ağlayıştır."Bozgun" ve "ufuk" kelimelerinin burada da birbiri ile irtibatlı olarak, hatta aynı mısrada verilmesi, yine tükenişi ve nihayete erişi anlatmak içindir. Akşamı ise gece yani esaret izleyecektir. Soru cümleleri ile başlayan şiir, yine soru cümleleri ile biter. Şair, şiir boyunca sorduğu beş soru cümlesi ile, memleketin duçar olduğu hali anlamada ve bilhassa kabullenmedeki zorluğu ifade etmiş olur.

Köprülüzâde Mehmet Fuat, "Yapma Edebiyat" adlı yazısında edebî eserlerin zamandan ve mekândan tecrit edilemeyeceğini, her sanatkârın, sanatının unsurlarını kendi çevresinden alarak milletinin hislerine tercüman olduğunu söyler. İmparatorluğun savaş ve mütareke sonrası halini "bir milletin hayatında görebileceği en büyük, en korkunç bir felaket” olarak niteledikten sonra Boğaz'da işgal güçlerinin donanmasını görmekten duyduğu elemi dile getirir:

"Vaktiyle Nedim'in ilâhî terennümlerini dinleyen Boğaz ve Haliç suları, bugün iri, korkunç heyulaların ağır gölgeleri altında susmuş, kıyılara ölüm besteleriyle vuruyor. Marmara'nın sedefli kumları üzerinde felaketimize kahkahalar kusan kitaresesleriyle, kanlı gözlerini eski, çarpık bir Kâbe üstündeki hilâle yabancı çiftler dolaşmakta!” (Büyük Mecmua, 1919: (1), 7)

Yazısının son bölümünde sözü tekrar "milletlerinin ruhunu dinledikleri zaman adeta birer resul hükmünde" gördüğü şairlere ve Türk şairlerine getiren Köprülüzâde Mehmet Fuat, onlara hitaben, "masum", "mazlum" ve "mahzun" sıfatlarıyla zikrettiği Türk milleti karşısında çok önemli sorumlulukları olduğunu hatırlatır ve üzerlerine düşeni yapmaları için yalvarır:

"Asırlardan beri felaketler arasında yuvarlanan masum ve mazlum Türk milletinin bir ferdi saffetiyle onlara yalvarıyorum: Ey şairler, muvakkaten ferdî aşk ve ihtiraslarınızı unutarak biraz Türk'ün felaketli ruhunu dinleyiniz; onun yaralarını sarmaya, sarsılmış hasta ruhunu ümit ve iman ateşleriyle doldurmaya çalışınız. (...) Sizler ey şairler bu büyük vazifenizi anlayarak, felaketle uyuşmuş bu mahzun halka karşı İsrafil'in Sûr'u gibi ilâhî bir sesle haykırınız: Haydi hayata, faaliyete, istikbale!" (Büyük Mecmua, 1919:(1), 7) 
Türk milletinin savaş ve sonrasında içine düştüğü durumun, yazar tarafından makalenin altı yerinde "felaket" olarak nitelenmesi, ayrıca dikkat çeker. Fakat ona göre, meselenin şuur ve ciddiyetinden uzak edebiyat mensupları da vardır. Onlar, bu "elem ve felaket günlerimizde" "şevk ve saadetle coşan Nedimâne gazeller, Sa'dâbâd şarkıları”, çıplak ve ekseriya müstehcen hikâyeler, yine aynı mahiyette adapte komedyalar yazmakla meşguldürler. Yazar, bütün bunları hayret ve teessürle karşllar. (Büyük Местиа, 1919: (1), 7)

Köprülüzâde Mehmet, Süleyman Nazifin eserini tanıttı̆̆ı "Firak-ı Irak"adlı bir başka yazısında Süleyman Nazifin "en samimi ve en âteşîn bir milliyetperver" olduğunu söyledikten sonra dilinin ağırlığının fazla bir önemi olmadığını belirtir. (Büyük Мecmua, 1919: (1), 10) Büyük Mecmua'da bu yazının altında “Firak-ı Irak'tan alınmış bir parça” notu ile “Anneme” adlı bölüm yayımlanır.

Süleyman Nazif, bu bölümde kabrini on senede ancak iki defa ziyaret edebilmek yüzünden karşısında kendini günahkâr ve suçlu hissettiği annesine hitaben, içinde bulunduğu günlerde ondan daha büyük ve daha "muazzez" olan vatanını düşündüğünü söyler. Büyük şairin eserinin bu bölümü, onun engin vatanseverliğinin ve derin elemlerinin bir başka şekilde ifadesi olan, fevkalade samimi, fevkalade içten ve sanatkârâne cümlelerle biter: "Ah anne! Keşke ben yalnız senin öksüzün olsaydım... Ve yalnız senin öksüzün olarak kırk sene evvel ölseydim de böyle yetim-i vatan ve yetim-i tarih kalmasaydım!... Senden çok bedbaht Oğlun" (Büyük Mecmua, 1919: (1), 10) 4

Sanatkârların, elem ve ıstırabı ifade vasıtalarından biri de, şehitlere ve ecdada duyulan minnetle beraber onlar karşısında yaşanılan mahcubiyet ve suçluluk duygularıdır. Yusuf Ziya "Günah" adlı şiirinde, daha önce memleket meseleleri ile ilgilenmemiş olmayı "cinayet kadar büyük" suç sayar. Zira vatanın bugün içine düştüğü durumun sebeplerinden biri de aydınların geçmiş zamandaki bu lâkaydîsidir. Bu sebeple onlar şimdi vicdan rahatsızlı̆̆ içindedirler:

"Mücrimim affet ihtiyar nine,

Bir mecnun ihtiras ile sarhoştum!

Bîgâne yaşadım senin derdine,

Aşk için ağladım, aşk için coştum!"(Büyük Mecmua, 1919: (8), 116)

M.F., "Şehitlerimize" adlı şiirinde aydınlar ve seçkinler adına "biz" derken hislerini şöyle dile getirir:

"Affediniz biz size lâyık değiliz;

Ayă̆ımız basmasın o topraklara.

Hatıranızı bile tutmadık temiz,

Ellerimiz çamurlu, yüzümüz kara!"(Büyük Мecmua, 1919: (3), 42)

Savaşı ve onun acı sonuçlarını vatan için "facia" olarak nitelendiren Falih Rıfkı, "Faciadan Sonra" adlı yazısında okuyucuya Yakup Kadri'den (Yaban'dan) yıllar evvel,olan bitenden aydınları sorumlu tutar. Birinci çoğul şahıs üzerinden konuşmasından ve "biz" demesinden, sorumlular arasına kendisini de kattığı anlaşılır:

"Dünyada hiç kimsenin günahı, Türk güzidelerinin günahı kadar ağır değildir.(...)

$4 \quad$ Süleyman Nazifin, İstanbul'un işgali üzerine Hâdisât gazetesinde yazdığı "Kara Bir Gün" başlıklı yazı, yazarının fevkalade cesareti sebebiyle bütün vatanseverlerce büyük takdir görür. Meselâ onu takdir edenlerden biri de Mehmet Âkiftir: "Âkif onu gördüğü zaman kahramanca yazılarını hatırlıyordu: 31 Mart’ta öldürülme tehlikesine rağmen yazdığı meşhur yazıyı Mütareke'de ‘Kara (Bir) Gün’ makalesini...”(Erişirgil, 1986: 369-370.) 
Anadolu'yu sergüzeştten sergüzeşte attık. Çıplak köylüler, cenupta çöllerden, şimalde soğuk dağlardan aştı. Birçoklarının, gittiği memleketin isminden bile haberi yoktu. (...) Bes sene sonra nihayete eren bu harp, Türk güzidelerinin aşağı mantığı, gülünç siyaseti ve bozuk ahlâkı üstünde kurulmuş bir facia ve Anadolu'nun saf, civanmert kanıyla yazılmış bir destandır. Bu vatana uzaktan bakanlar, güzidelerin iğrenç iflâsını ve halkın azametini görür. Şimdi bize bir iş kaldı. Türkleri kendi topraklarında bırakmak ve rahat birakmak...” (Büyük Mecmua, 1919: (10), 148)

$\mathrm{Bu}$ dönemde hem devletin hem işgalgüçlerininsansürü altındavarlığını sürdürmeye çalışan yayın organları ve onların mensubu yazar ve şairlerin, fikir, duygu ve düşüncelerini anlatmak için dolaylı anlatımı, teşbih, istiare ve telmihleri tercih ettikleri görülür. Altı yüz yllık imparatorluğun hazin çöküşünü felaket veya facia olarak niteledikten sonra elem ve ıstırap duygularını ifade için en çok başvurdukları benzetme, "gurup" istiaresidir.

\section{Dua ve yalvarışlar}

Tarihinin her döneminde dinî inancı ve imanından kuvvet almasıyla bilinen Müslüman Türk milletinin, içine düştüğü yalnızlık ve çaresizlik ortamında Allah'a sığınması, hem dinî inancı hem kendini savunma refleksi bakımından tabiidir.

Mehmet Emin, "Tanrıya" adlı şiirinde ulu tanrının adını daha beşikte iken öğrendiğini, çocukken mescide gidip dua ettiğini belirttikten sonra şimdi yine ona samimiyet ve safiyetle sığınmak istediğini belirtir:

"İşte yine bu ruhla geldim senin mabedine;

Anıorum secdemde bir riyasız dille seni;

Açıyorum lekesiz ellerimi sana yine;

Kutluyorum sarsılmaz bir imanla mucizeni.” (Büyük Mecmua, 1919: (1), 10)

Kemalettin Kâmi, halk tasavvuf edebiyatının ilâhi nazım şekline uygun olarak, rahat ve tabii bir Türkçe ile yazdığı "Türk'ün İlâhîsi” adlı şiirinde memleketin her yanının matem içinde olduğunu, millet olarak yalnız kaldığımızı, etrafımızdaki çehrelerin (işgalciler) bize yabancı olduğunu söyler ve her dörtlüğün son mısraında "Yarabbi" diyerek Allah'a yalvarır. Şiirin sonunda, millet olarak uğranılan hali, diğer kalem arkadaşları gibi o da "felaket” olarak görür, Mütareke ve işgal dönemini de geceye benzetir:

"Bir gün sabah olur diye,

Katlandık her işkenceye...

$\mathrm{Bu}$ felaketli geceye...

Ver bir nihayet Yarabbi!”(Büyük Мecmua, 1919: 9, 133)

Faruk Nafiz, "Münâcât" adlı şiirinde Allah’a kendisi için yalvarır görünür. Nitekim dokuz dörtlükten oluşan şiirin altı yerinde "ben" zamirini kullanır. Fiil çekimleri de metnin tamamında birinci şahıs üzerinden yapılır. Fakat okuyucu, sanatkârın, ikinci ve sekizinci dörtlüklerde "bir ırk" ve "ülke" adına konuştuğunu görünce Allah’a isyan sınırına gelmiş şairin, şiirini aslında memleket için yazmış olduğu fikrine ulaşır:

“Dediler 'Bu akşam dua gecesi!'

Geldim huzuruna diz çöktüm yine.

Aşina çıkarsın bu garip sesi

Dinlersen bir urkın elemlerine.”

\section{$\cdots$}


Hiç kimse bilmiyor nedir saadet.

Kahrına uğramış sanki ülkemiz.

Bu çllgın sözlerim isyansa affet,

Sahille dövüşür kuduran deniz!(Büyük Mecmua, 1919: (9), 132)

Yusuf Ziya, bentler halinde yazdığı uzun "Ramazan Gecesi" adlı şiirinde Faruk Nafiz gibi o da duygularını kendisi üzerinden dile getirerek Allah'a sığınır ve ona yalvarır. Fakat maksadını ifadesi, Faruk Nafiz'e göre daha açık, vurgulamaları daha kuvvetlidir:

"Bu ne? Bu gördüğüm yer, bu viran ülke nedir?

Rabbim... Bu vatanım mı? Bu mudur benim yurdum?

Bu akşam her tarafta bir ruhanî hüzün var,

Bir ses bana diyor ki: Şair Allah’a yalvar!

Kirpiklerim yaşardı, düştüm yeni bir vecde;

Yıldızların altında ettim Allah'ıma secde!

Tanrım... Ne kadar hazin, ne kadar kara yazım;

İlk defa huzurunda diz çöken bu niyazım

Yurdunun matemini duyan bir âşık sesi;

Seninki şu göklerin adaletinin makesi,

Bense zulmet içinde arıyorum biraz nur,

O halde münâcâtım elbet kabul olunur.” (Büyük Mecmua, 1919: (9), 132)

Hüzün, kara yazı, niyaz, matem, zulmet ve münâcât kelimeleri şairin elem içinde yalvarışını daha belirgin olarak fark ettirir.

Orhan Seyfi, “Annemin Duası” adlı şiirinde annesinin bir duasını kaydeder:

"Yarabbi, daima alnımız kara,

Nasil varacağız böyle huzura!"

Yarabbi, sığındık merhametine;

Büsbütün ümitsiz değiliz yine!”

Şiirin dua bölümünde altı mısra "Yarabbi" diye başlar. Anne, Allah’ın merhametine sığınır, ondan oğlunu karşlaşabileceği tehlikelerden korumasını ister. Zira anne sezgi olarak, gelecekten, memleketin geleceğinden endişelidir. Annenin bu endişesi ve duası, oğlunu ürkütür. Fakat oğlu, geçmişte karşılaştığı felaketleri her seferinde annesinin duası sayesinde savuşturabilmiştir, şimdi de ona güvenmektedir:

"O zaman muhakkak bir felaketi

Başımın üstünden çevirir geri

Annemin duaya kalkan elleri."(Büyük Mecmua, 1919: (11),174) 
Büyük Mecmua'da neşredilmiş dua ve yalvarış metinleri içinde en etkileyici olanını Sabiha Zekeriya'nın kaleme aldığını ifade etmek lâzımdır. Yazar, "Son Dua” adlı yazısında söze "Allah’ım!" diye başlar; yalvarış ve yakarışlarını fevkalade içten, çok canlı, kıvrak bir Türkçe ile sürdürür. Türk milletinin, dinî ve millî mukaddeslerine bağlllı̆̆ını yüksek bir heyecanla dile getirdiği bir sahifelik metin boyunca Allah'a sık sık seslenirken "Allah'ım" ( on iki defa), "Yarabbi” (beş defa), "Tanrım" (bir defa) hitaplarını kullandığı görülür:

\begin{abstract}
“Allah'ım!
Ak saçlı ihtiyarlar, bağrı yanık analar, gönlü yaralanmış yetimler, bütün Türk ve Müslüman kulların hep birden duaya geldik... Sesimiz, sana minareler memleketinin bütün Müslüman dünyasına ses veren mabetlerinden yükseliyor.... Kalbimizi sana açtık. Gözlerimizde senin, Türk kalbimizde senin, ruhumuzda senin aşkın var... Mabetlerinde ağlayan, surların üzerinde feryat eden, bütün Müslüman iklimlerinde matem tutan yaslı Türk sedasını işiten Tanrım!.. Bizi de dinle, ruhumuzdan kopan feryatlara acı ve bizi koru Allah'ım. Günahlarımıza tövbeler ederek, şehitlerimizin ruhundaki kutsiyete sığınarak sana secde ediyoruz. Müslüman ruhunu temsil eden camilerine haç diktirme Allah'ım. Yedi yüz seneden beri minarelerinde okunan ezan sesine bizi hasret etme Allah'ım. Topraklar altında millet için ölen şehitlerini mezarında ağlatma Yarabbi. Babaları için ağlayan bir milyon yetimin hıçkırıklarını işit, bizi o şehitlerin ruhu hürmetine sıyanet eyle Yarabbi. Yedi yüz seneden beri denizlerin hakimi, şarkın hükümranı olduk, bizi düşmanlarımıza esir eyleme Yarabbi!
\end{abstract}

Huzurunda diz çöktük, sana bütün vecdimiz, bütün imanımızla yalvarıyoruz. İmdat dileyen yaşlı gözlerimiz, merhametine sığınan matemli kalplerimiz, hicran dolu ruhumuzla sana ibadet ediyor ve yalvariyoruz:

Hükümran olduğumuz topraklarda bizi süründürme Allah’ım!

Camilerimizde yanan din ve iman kandillerini söndürme Allah’ım!”(Büyük Mecmua, 1919: (9), 134)

Sanatkârların, Allah'a sığınma ve yalvarış duygularını kendi şahısları üzerinden fakat bütün bir Müslüman kütle adına dile getirdikleri görülür. Zikredilen metinlere hakim çok yoğun yas hali ve matem duygusu, dua ve yalvarışların zeminini oluşturur.

\title{
3. Gayrimüslimler
}

Şairler ve yazarlar, eserlerinde gayrimüslimlerin Mütareke ve özellikle işgalle birlikte değişen hal ve tavırlarına teessürle yer verirler. Fakat, yukarıda da belirttiğimiz gibi, hem Osmanlı hükümetinin hem işgal güçlerinin sansürüne maruz olan basın ve yayın dünyası, bu çifte baskı altında her fikir ve düşünceyi açıkça söyleyemez.

Yusuf Ziya’nın “Ölü Evinde Düğün” şiiri, böylesi metinlerin okuyucu için hayli kapalı örneklerinden biri sayılabilir. Ölü evi ve düğün şeklindeki istiareler, maksadı örtülü fakat veciz bir tarzda ifade bakımından isabetli ve orijinal sayılmak gerekir. Ölü evi, matem içindeki Türk ve Müslüman İstanbul (veya Türkiye) ise bu evde düğün yapanlar da gayrimüslimlerdir:

"Bu ulvi matemin önünde her ses

Susuyor bir mahzun ihtiram ile.

Aynı ıstırabı duyarken herkes

Kimdir bu gülenler intikam ile?

$\mathrm{Bu}$ ölü evinde gelin olacak kim?

Bu mezar önünde ah kimler güldü!

Uğrunda titrerken varlığım, sevgim, 
Kabrinin üstünde boynum büküldü!(Büyük Мecmua, 1919: (4), 56)

Ömer Seyfettin, "Memlekete Mektup" adlı hikâyesinde İstanbul'un ve orada yaşayan gayrimüslimlerin harp sonrasındaki durumunu hikâye başkahramanının, arkadaşına yazdığı bir mektup üslubuyla tasvir eder. İstanbul artık eski İstanbul değildir. Herkesin üstü başı perişan, çehreler solgundur. İnanılmaz bir çaresizlik, yoksulluk ve sıkıntı halkı ezmektedir. Mahallelerde birçok ev açtır. Buna karşılık birtakım insanlar debdebe ve şaşaa içinde günlerini gün etmektedirler:

"Fakirlikle zenginlik, iki barışmaz düşman gibi karşı karşıya geçmiş. Biri karargâhını Şişli’ye, Nişantaşı'na, öteki Fatih'e, Aksaray'a kurmuş. (...) Avrupa'nın, Asya'nın her türlü askerî üniforması göze çarpıyor. En neşeli halk Rumlar... Lâtarnalarıyla sokakları dolaşıyorlar, hiç durmadan ötüyorlar, gülüyorlar, şarkı söylüyorlar, içiyorlar, nara atıyorlar.” (Büyük Mecmua, 1919: (2), 30)

Ömer Seyfettin ve onun gibi, imparatorluğun payitahtında yaşayan sanatkârlar, Mütareke İstanbul'unda olayların yakînen şahidi olurlar, hatta bazen olayları bizzat yaşarlar. Bu sebeple döneme dair tespit ve anlatımları tarihî malûmatla genellikle benzeşir. 5

Hikâyenin sonuna doğru memleketin ve İstanbul'un içinde bulunduğu durumu, çoğu şair ve yazar gibi Ömer Seyfettin de "felaket" olarak niteler. Ancak, o, saadetin de felaketin de geçici olduğunu hatırlayıp teselli bulur.

Halide Edip, "Zeynebim Zeynebim" adlı hikâyesinde İzmir yakınında modern usulde çiftçilik yapan zengin bir Türk'ün yanında çalışan iki Rum'un ve çevre köylerdeki Rumların, İzmir'in işgalinden sonraki değişim ve hıyanetlerini anlatır. (Büyük Мecmua, 1919: (17), 262)

Sonuç olarak sanatkârlar, yüzlerce yıldan beri beraber yaşadığımız gayrimüslimlerin, savaş ve Mütareke sonrasındaki şımarıklık, küstahlık ve hıyanetleri karşısında şaşkınlık ve elem duyarlar.

\section{4. Ümit ve inanç}

Halkı ve özellikle gençleri karamsarlıktan çıkarıp kurtuluş ümidi ve inancına doğru istikamet sahibi yapmak ilkesinden hareketle yayın hayatına başlayan Büyük Mecmua'nın, esas itibarıyla bütün yayınlarında bu maksadın tahakkuku hedeflenmiştir. Şairler ve yazarlar, derecesi veya yoğunluğu değişmekle birlikte hep bu hususa katkı yapmak gayretinde olmuşlardır.

Orhan Seyfi, "Kara Bayrak" adlı şiirinden önce nesirle bir giriş yapar: Al bayrağımız, sevgili sancağımızın bugün bütün Müslümanların başları üstünde siyah, derin bir matem içinde dalgalandığını belirtir. ${ }^{6}$ Onun bu matemi karşısında ezilmeyen, titremeyen hiçbir Türk, hiçbir Müslüman kalmamıştır. (...) (Büyük Мecmua, 1919: (9), 44)

Sonra şiirine geçer. Bayrağın önceki rengi (kızıl) ile şimdiki rengini (kara) mukayese ettikten sonra onu tekrar eski rengine çevirecek asalet ve cesarete sahip olduğumuzu söyler. Kendi ümit ve iyimserliğini sancă̆a da yansıtmak ister:

5 “...Müslüman Türkler kabuklarına çekilmişlerdi. İşgalin başlamasıyla birlikte sahil boyunca Rum, Ermeni ve Yahudiler büyük sevinç gösterileri yaptılar. Azınlıkların yaşadığı mahallelerde ve evlerde pencerelerden yerlere kadar sarkan büyüklükte işgal devletleri bayrakları asılmıştı. Kentte birçok binanın cephesini boydan boya kaplayan Yunan bayrakları asılmıştı. Sokaklarda ve meydanlarda "Zito Venizelos" (Yaşa Venizelos) diye bağıran gruplar kutlamalar yapıyor hatta hora tepiyorlardı. Şehirdeki tüm Rum ve Ermeni kiliselerinde işgal güçleri kutsanıyordu.” (Akıncı, 2020: 411.) İzmir'in işgalinden sonra yapılan Sultanahmet mitingi ve diğer mitinglere halk, ellerinde siyah bayraklarla katılmıştır. Konuşmacı kürsülerine de siyah örtü örtülmüştür. (Akıncı, 2020: 193.) 
“Ey güzel sancağım, solmasın yüzün,

Biz henüz yaşarken yasa bürünme!

Hicrana takati yok gönlümüzün,

Bu matem yüzüyle bize görünme!”(Büyük Мecmua, 1919: (9), 44)

Yine Orhan Seyfi, "Sancağa" adlı şiirinde memleketin içinde bulunduğu derin matem duygusunu hem milleti daha büyük sıkıntılara sokabileceği endişesiyle hem de günah endişesiyle doğru bulmadığını ifade eder:

"Ellerde dolaşan bu siyah sancak,

Göklere yükselen bir ah olmasın!

Doğru mu bu kadar yeise kapılmak;

Korkarım, bu matem günah olmasın!”

Milleti temsil eden sancağın siyah olması, milletçe yaşanılan matem sebebiyledir. Şair, şiir boyunca duygu ve heyecanlarını, kişileştirdiği "siyah sancak"a hitap ederek dillendirir. Ona göre, kederlenmeye lüzum yoktur. İşgal ve esaret, zamanın hadiseleri değiştirme kudreti sayesinde giderek kurtuluş ve hürriyete dönüşecektir:

"Milletin kalbinde yer etmez keder,

Asırlar değişir, seneler geçer.

Ne kadar karanlık olsa geceler,

Mümkün mü sonunda sabah olmasın!”(Büyük Мecтua, 1919: (9), 132)

Faruk Nafiz de "Bugün" adlı şiirinde millî matemi sembolize eden "siyah sancak" öğesine yer verir; ardından, kurtuluşa ve hürriyete olan inancını dile getirir:

"Yeisini duyarak biz bu diyarın

Siyaha boyadık sancağımızı,

Bu karanlıkları yırtarak yarın

Âtiye doğacak Türk'ün yıldızı.” (Büyük Mecmua, 1919: (10), 152)

Avni Sadi, "En Sevgiliye" adlı şiirinde vatanı en çok sevilen sevgili olarak tarif eder ve onu kişileştirir. Ümitli ve iyimser bir bakışla, onun, bugün de gelecekte de bizim olacağını söylerken inancını ve kararlılı̆̆ını ortaya koyar:

"Matem sesleri var ufuklarda...

Seni benimseyen bu yabancı kim?

İsmini duyunca kastını bildim!

Her gün bizimsin sen, elbet yarın da...” (nu:10, s. 152)

Faruk Nafiz, "Yaralı Arslan" adlı şiirinde Mehmetçik’i yaralı bir arslana benzetir ve onun kahramanlığını över:

“...

Bahtınla boy ölçtün yiğit çağında.

Şerefli dövüştün şanlı vuruştun, 
Kazıldı mezarın Kafkas dağında...”

Şiirin son dörtlüğünde ise Mehmetçik’in yükseldiği mertebeyi ve ona, onun en yakın insanlarına duyduğu engin sevgiyi dile getirir:

"Âlemde esirdin, cennette hürsün,

Yadını kâbil mi toprak öldürsün?

Kalbimi yararsam sen görünürsün

Nişanlın solunda, ninen sağında!...”(Büyük Мecтua, 1919: (7), 103)

Halide Edip, "Dağa Çıkan Kurt" (Büyük Mecmua, 1919: (13), 197) adlı hikâyesinde harpte babasını kaybetmiş bir kız çocuğunun rüyasını hikâye ederek, bütün vahşi hayvanların saldırısı karşısında tek başına kalan kurdun var olma mücadelesini anlatır. Teslimiyeti kabul etmeyen kurt; gurur, haysiyet, inanç ve direnciyle Türk milletini temsil eder.(Büyük Мecmua, 1919: (13), 197)

Bu metinlerden başka, Ömer Seyfettin'in, haksızlığa, zulme karşı mücadele fikrini işleyen "Yalnız Efe" (Büyük Mecmua, 1919: (11), 174) ve insanımıza ecdadından ilham ve kuvvet alarak kendine güven duygusu telkin amaciyla yazılmış "Forsa" (Büyük Mecmua, 1919: (1), 14) hikâyeleri, Büyük Mecmua'da yayımlanmış savaş sonrası edebî verimleri olarak dikkat çekerler.

Sanatçllar, ümit ve kurtuluşa inanç telkin etme işini Mütareke sonrasının ilk aylarında dolaylı anlatımla, 1919 Haziranından itibaren ise (nu:9 ve devamı) daha açık ve daha heyecanlı bir söyleyişle yaparlar. Bunda, onlar açıkça ifade etmeseler de, Mustafa Kemal Paşa'nın Samsun'a çıkıp millî kurtuluş hareketini başlatmış olmasının tesiri muhakkaktır.

\section{Mefkûre}

Büyük Mecmua'daki bazı sanatkârlar ise ümit ve inanç temi ile birlikte mefkûre fikrini de işlemişlerdir. Tabii olarak, başka eserlere göre biraz didaktik mahiyette kalan bu şiir ve yazllar, yine de, sanatkârların fikir ve düşüncelerini tespitte, döneme, cemiyete ve gençliğe bakışlarını anlamada yararı olabilecek metinlerdir.

Mehmet Emin, "Millî Ruh" adlı şiirinde bir gece gördüğü rüyayı hikâye ederken "bir semavi nur”un millı̂ ruhu kendisine "bir kevser", "bir mukaddes iksir" olarak sunduğunu söyler:

"Dedi: 'Al iç ve içir; bir mukaddes iksirdir bu!

Bu kalplerde kıvılcım, alınlarda nur yaratır;

Aradığın her bir şey; ümit, şifa hep bundadır.”(Büyük Мecmua, 1919: (1), 11)

Şairin, "iç ve içir" deyişinden, kişinin, milletinin karakterini ihtiva eden millî ruhu benimsemekle kalmayıp başkalarına da benimsetmesi öğüdü anlaşılır. Şaire göre, insan millî ruh sayesinde heyecan ve safiyet kazanır. Arayış içinde olan gençliğin, her türlü elem ve sıkıntısı millî ruha sahip olmakla bitecek, her türlü ümidi onun sayesinde gerçekleşecektir.

Mehmet Emin'in, aynı mecmuanın aynı sayısında yayımlanan "Ümit" şiiri, firtına tarafından yuvası bozulan bir bülbülün, önceleri mustarip iken zamanla ümit ve iyimserliğe doğru değişimini konu alır ve bu değişimiyle bülbül, şaire müspet bir örnek olur. Mehmet Emin, bülbül istiaresi vasitasıyla ümit ve inancın insanı etkileme ve yükseltme gücünü anlatmak ister: 
"Sonra sana hangi el; çiçek, ziya, aşk gönderdi;

Kimler senin nağmene yeni bir ruh, ahenk verdi;

Söyle sana bunları veren kimdir, hangi kuvvet?”(Büyük Местиa, 1919: (1), 11)

Şairin yine birinci sayıda neşredilen "Mefkûre" şiiri de önceki şiirler gibi, ferdin ruh ve iman terbiyesini merkeze alır. Sanatçı, kişileştirdiği mefkûreye "sen" diye hitap eder ve mübalâğa yaparak, onda "Allah füsunu" ve "resul ruhu" kudreti görür. Tarihte başarılmış büyük işler, insanlığı etkilemiş büyük fikirler, hep, ülkü sahibi fert ve toplumların eseridir:

"Dünyaların fecridir senin sesin, senin nurun;

Eski, yeni tarihi yapan senin ellerindir;

Medeniyet, hürriyet, her şey senin eserindir!”(Büyük Mecmua, 1919: (1), 11)

Aynı dönemde Yusuf Ziya da "Mefkûre" adıyla bir şiir yazar. Dört kıta, iki beyit ve altı bentten oluşan uzun manzumesinde şair, çeşitli ruh gel-gitlerini, muhayyel seyahati esnasında vardığı farklı mekânların öğeleri vasıtasıyla anlatırken sözü "hal"e getirir: Şimdi bütün âlem kızıl kana bulanmış, ordular çiğnenmiş, beldeler yanmıştır. Bir yanda galip, bir yanda mağlûp vardır. Bu beklenmedik durum, şaire göre bir "kızıl haile"dir. (Büyük Мecmua, 1919: (2), 24) Şiir boyunca kâh ümit kâh karamsarlık duyguları arasında kalan şair, son bentte sözü fantastik bir tabloda mucizevî bir hadiseye getirir, en son mısrada ise asıl mesajını verir:

"Gök yarıldı, güldü derin, ürpertici bir nağme,

Yedi renkli bir merdiven itti hemen önüme!

Diyordu ki: Rüyamın hitabını dinle şair,

Sizi dertten kurtaracak bir ilâhî mefkûredir.(Büyük Mecmua, 1919: (2), 24)

Mecmuanın birinci sayısında “Büyüklerimiz” başlığı ile mecmua adına yazılan takdim yazısında:

“Büyük Mecmua’nın gayelerinden biri de gençliğe îman ve mefkûre vermektir. Bizi ruhlarımızı günün sefaletinden kurtarıp yükseltecek şey, hiç şüphesiz ki yüksek ve büyük ruhların büyüklükleridir. Gençlik, önünde mefkûre ve îman uğruna hayatını istihkar eden büyüklerimizi görüp öğrendikçe yaşamak hak ve kabiliyetimizi daha iyi anlayacak ve zamanın adi ve sefil ruhlarından çok daha yüksek Türklerin de bulunduğunu görecektir.”(Büyük Mecmua, 1919: (1), 16)

denildikten sonra her sayıda “yüksek ruhlu adamlarımız”dan birinin gençliğe tanıtılacağı belirtilir.

Mecmuanın bu yayın ilkesine uygun olarak birinci sayıda, zamanın örnek şahsiyetleri olarak, Medine Müdafii Fahri (Fahrettin) Paşaya, ikinci sayıda büyük ilim adamı Salih Zeki Bey’e, üçüncü sayıda Çanakkale kahramanlarından Mustafa Kemal Paşa'ya yer verilir. Üçüncü sayıda M. Z. imzası ile yazılan "Mustafa Kemal Paşa" adlı yazıda, Batı'da büyük şahsiyetlere gösterilen hürmet ve tazimi anlatan uzun bir girişten sonra, söz, Çanakkale muharebesine ve onun başarılı komutanlarına getirilir:

“...Çanakkale muharebesi bize bir çok muvaffakiyetlerden mâadâ, bir de [Mustafa Kemal] kazandırmıștır. Osmanlı tarihinin en şerefli bir sahifesini işgal edeceğine şüphe olmayan Çanakkale muvaffakiyeti, orada çarpışan Türklük ruhunu, Türklük fedakârlığını ispat ettiği gibi, bir de Mustafa Kemal gibi büyük bir kahramana malik olduğumuzu gösterdi. Tarih, Çanakkale vak'asını kaydederken hiç şüphesiz Mustafa Kemal ve Cevat Paşaların isimlerini de altın harflerle yazacaktır.” (Büyük Mecmua, 1919: (3), 44) 
Mecmuanın yayın amacına uygun olarak sanatkârlar, ilk sayıdan itibaren, gençliğe mefkûre kazandırma lüzumuna bütün mantık ve duyarlılıkları ile katılırlar. Kendilerini, bazen, aynı isimde (Mefkûre) eser yazmayı önemsemeyecek derecede (Mehmet Emin-Yusuf Ziya) konuya adapte etmişlerdir. Onlar için asıl önemli olan, gençliğe ulaşmak ve ona müspet istikamet vermektir.

\section{6. İzmir}

Mondros Mütarekesi'nden sonra her türlü menfi gelişme herkesi müteessir etmekle birlikte, o dönemde vatansever Türk aydınlarını derinden sarsan en büyük olay, İzmir’in Yunanlılar tarafından işgalidir. Bu hadise onlar üzerinde âdeta şok etkisi yapar. Bundan dolayı zamanın şair ve yazarlarının o günlere mahsus yazılarında en çok geçen şehir adı, İzmir'dir.

Halide Edip, "İtilâf Milletlerine" adlı yazısında işgal hadisesini "İzmir faciası" diye niteledikten sonra, Batı kültürü ile yetişmiş biri olarak, Avrupa'nın bu saldırgan tutumu karşısında hayal kırıklı̆̆na uğradığını belirtir. (Büyük Мecmua, 1919: (9), 130)

İzmir'in savaş kaybederek değil, Mütareke yüzünden elimizden çıktığını düşünen Faruk Nafiz, hem kendi şaşkınlık ve üzüntüsünü hem halkın elemini "Ey İzmir" adlı şiirinde şöyle ifade eder:

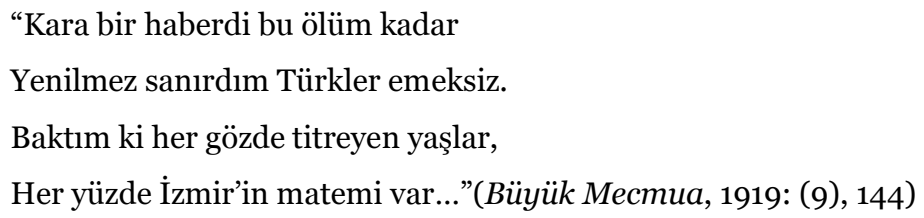

Falih Rıfkı, "Facianın İki Tarafı" adlı yazısında İzmir’in işgalini duyunca inanamadığını belirttikten sonra "Ne yazık ki, bu haber (sansür) ve Erzurum'la Trakya arasında yaşayan bütün Osmanlı Türklerini yüreklerinden sarstı.” der. Daha sonra sözü, işgalleri protesto için yapılan mitinglere ve o toplantılara siyah Osmanlı bayrakları ile katılan Türk kadınlarına getirerek, hepsinin, Yunan bayraklarında ölümün kızıl dişlerini gördüğünü (Büyük Mecmua, 1919: (9), 31) belirtir. Zira hepsi "İzmir faciası"ndan haberdardır. Falih Rıfkı, "Sevgili İzmir" adlı bir başka yazısında İzmir’in Türklüğü bahsinde, Rumların oturduğu Kordon'un arkasının, Sarı Zeybek’in gezdiği dağlara kadar Türk olduğunu söyler. (BüyükMecmua, 1919: (8), 115) Kısa süre sonra yazdığı "Facianın İki Tarafı"nda ise daha açık ve kesin konuşur ve bu aynı zamanda, Batlıların Türkiye'yi parçalama, başkalarına peşkeş çekme ihtiraslarına karşı verilmiş bir cevaptır: "İskenderiye Arap olduğu kadar, Marsilya Fransız olduğu kadar, İzmir de Türk’tür.” (Büyük Mecmua, 1919: (9), 31)

Büyük Mecmua'da imzasız olarak yayımlanan “İzmir Türk’tür ve Türk Kalmalıdır” adlı yazıda da İzmir’in, tarihen Türk olduğu gibi, o günkü nüfus çoğunluğu itibarıyla da Türk olduğu (1.2490oo Türk, 299000 Rum) kaydedilir. Hal böyle iken "Bugün bir emrivaki karşısında bulunuyoruz." (Büyük Местиа, 1919: (9), 136) diyen yazar, özü itibarıla, Türklerin direnmek mecburiyetinde olduklarını ifade eder.

Mecmuanın aynı sayısında, sözünü ettiğimiz bu imzasız yazının altındaki "Millî Galeyan” adlı diğer bir imzasız yazıda da, İzmir’in işgali karşısında kamuoyunun gösterdiği derin hassasiyet ve dinamik tepki, ustalıklı bir anlatımla tasvir edilir:

“İzmir'in işgali gününden beri, memlekette umumî bir galeyan var. Bu defa hançerin kalbine saplandığını hisseden Türk, can havliyle bağırmak ihtiyacını duyuyor ve sokaklara dökülerek her 
tarafta haksızlığa, zulme karşı bağırıyor, çırpınıyor. 'Ben adalet istiyorum, siz bana kurşunla mukabele ettiniz' diyor.”(Büyük Мecmua, 1919: (9), 136)

Yusuf Ziya ise "Eğil Dağlar Eğil" adlı şiirinde, yöre halkının temsilcisi konumundaki genç "efe"ye seslendiği mısralarında, işgali şaşkınlık göstermeden karşlar ve onu reddetmek suretiyle bir karşı duruş gösterir. İnsanların büyük çoğunlukla ümitsiz, moralsiz olduğu o günler Türkiye'sinde bu karşı duruş çok önemlidir:

“Ey güzel İzmir’in kahraman oğlu

Bir lâhza birakma tuttuğun yolu.

Bizim de bağrımız firtına dolu,

'Eğil dağlar eğil üstünden aşam'

Sevgili yurduma ben de kavuşam!”(Büyük Мecmua, 1919: (9), 144)

İzmir’in işgalini konu alan metinlerde en çok, olayın Türk milleti için bir facia olduğuna, akabinde de İzmir’in Türklüğüne vurgu yapıldığı görülür.

\section{7. İstanbul}

İzmir’in işgalinden sonra aydınları ve halkı endişe ve ıstıraba sevk eden bir diğer olay, İstanbul'un işgalidir.7Büyük Mecmua'nın yazar ve şairleri, İzmir kadar olmamakla birlikte, nesir ve şiirlerinde bu konuya da yer vermişlerdir.

Ruşen Eşref, "Bıraktığım İstanbul-Bulduğum İstanbul” adlı yazısında görevle bulunduğu Bakü'den savaş bitince İstanbul'a dönüşünü anlatır. Karadeniz üzerinden yaptığı vapur yolculuğu esnasında Boğaz'a girince dikkatini çeken ilk şey, yabancı bayraklar olur. Sonra biraz daha ilerleyince "minareler ve kubbeler şehri” İstanbul'un önüne bir "su şehri”nin kurulmuş olduğunu görür. "Su şehri” tamlaması ile kastettiği manzara, Dolmabahçe önüne demirlemiş, altmış bir gemiden oluşan düşman donanmasıdır. Cedlerin yadigârı İstanbul karşısında derin elem ve keder içinde kalan yazarın, Sirkeci'den İstanbul'a çıktıktan sonra şaşkınlığı daha da artar. İki-üç ay önce isimleri duyulmamış muhalif gazete ve mecmualar, şimdi bağıra çağıra satılmaktadır. Hepsi, kaba, hatta galiz bir üslupla İttihatçllara ateş püskürmektedir. Bu, iktidardan düşen her hükûmet ve zümrenin değişmez kaderidir.

Yazar, İttihatçlları millete yaşattıkları acılar sebebiyle eleştirir. İşgal güçlerinin İstanbul'a gelişi de onların hatalarının bir sonucudur:

“O sabah iki üç aylık gurbetten sonra kavuştuğum buruşuk ve mecalsiz İstanbul'da her şey, yaldızlı bir hırsın millete bıraktığı acıyı takrir ediyordu: Bellerinde dizkapaklarına sarkan etekliklerle İngiltere'nin Arnavutları sanılacak gaydalı ve davullu bir İskoçya kıtasının geçişi; (...) Üzerlerinde şilingleri, frankları, leyileri, dolarları, drahmileri bizim paraya tahvil edeceğini haber veren İngilizce, İtalyanca, Fransızca, Rumca yazılı camekânlar, o yeni kambiyo sergi ve tuzakları... Dört senedir görmediğimiz bayraklar, iki ay evvelki bayrakların yerine sarkıyor. Ve etraflarında her ordunun klyafeti ve her lisanın gürültüsü...

Tramvaylar durmuş. Herkes sokaklara dökülmüş. Öyle iken fesler ve çarşaflar seyrelmiş. Bir aşina yüz yok. İstanbul'un içinde İstanbul'u kaybettim.”(Büyük Mecmua, 1919: (8), 116)

\footnotetext{
7 “13 Kasım 1918'de İngiliz, Fransız, İtalyan ve Yunan gemilerinin teşkil ettiği 61 parçadan oluşan İtilâf devletlerinin filosu İstanbul'a gelmiştir. Donanma Dolmabahçe önünde demirlemiştir." (Eroğlu, 1982: 159) 16 Mart 1920’de de şehir, resmen ve fiilen askerî işgale maruz kalacaktır. (Eroğlu,1982: 201)
} 
Şehir, Ruşen Eşref'e, cadde ve sokaklardaki hareketliliğe rağmen çok yabancı görünür. Çünkü kalabalıklarda "fesler ve çarşaflar"ın, yani Türk ve Müslümanların sayısı eskiye nazaran azalmıştır. Yazarın, "İstanbul'un içinde İstanbul'u kaybettim." cümlesi, bütün bir yazının özeti gibidir; hem İstanbul'un hızlı ve aşırı değişimini hem de yazarın bu değişim ve yabancılaşma karşısında duyduğu şaşkınlık ve üzüntüyü ifade eder.

Yusuf Ziya, "İstanbul” adlı kısa şiirinde İstanbul'u kişileştirerek ona seslenir, işgalden dolayı onun matemini tuttuğunu, onu aşk derecesinde sevdiği halde, ihmal ettiği için suçluluk duyduğunu söyler:

"Ey İstanbul, şu mukaddes matemi dinle,

Genç, ihtiyar ağllyoruz senin derdinle!...

Affet seni ihmal eden bu vefasızı;

Bugün aşkın içimde bir ebedî sız!!”

Şair, beş vakit okunan ezanların, mezarların ve "binbir minare"nin şehrin aidiyetini gösteren çok önemli unsurlar olduğunu ihsas eder:

"Beş vakitte ezanlarla zulme karşı çık!

Âşıkların ağlaşıyor, düşmanların şen;

Yetim issız mezarlarla dolu her köşen!

Seni binbir minarenle âlem tanısın:

Uğrunda can verenlerin öz vatanısın!"(Büyük Мecmua, 1919: (5), 70)

Münir Tevfik, "Sen Hasta İken” adlı yazısına, Yusuf Ziya gibi, İstanbul'a hitap ederek başlar, sonra ölüm döşeğinde bir hasta gibi gördüğü İstanbul karşısında matemini ve ıstırabını dile getirir:

"İstanbul!

Yeisimin kalbime akan zehriyle acısı büyüyen bir matem içindeyim. Çünkü sen hastasın, çünkü sen muzdaripsin! Yatağının ucunda hepimiz sustuk. Ağladığımızı yabancılara göstermemek için, yaşlarımızı içimize döküyoruz. Hıçkırıklarımız seni incitmesin diye korkak ve sessiz...”(Büyük Местиа, 1919: (9), 115)

İstanbul'un işgali; sanatçları, işgal kuvvetlerinin saygısız, cüretkâr tavır ve icraatlarının yanı sıra, şımarmış gayrimüslimlerle iş birliği içinde şehri Müslüman-Türk kimliğinden uzaklaştırma yolundaki rencide edici çabaları bakımından ilgilendirir. Fakat, yazar ve şairlere göre, onların, bu "minareler ve kubbeler şehri”nin kimliğini değiştirmeleri mümkün değildir.

\section{Sonuç}

Mondros Mütarekesi’nden (30 Ekim 1918) Mustafa Kemal Paşa'nın 19 Mayıs 1919'da Samsun'a çıkışına ve Kongrelere kadar geçen süre, Osmanlı Devleti ve Türk milleti için çok önemli bir zaman aralığıdır. Ordunun dağıtıldığı, silâhların alındığı, işgallerin başladığı, padişah ve hükümetin acz içinde kaldığı, ekonominin felç olduğu bu dönemde, on yıldan beri peş peşe gelen savaşlar yüzünden yılgın ve yorgun olan halk ile yoğun bir ümitsizlik, karamsarlık içinde bulunan gençlik ve aydınlara ümit, iyimserlik, cesaret telkinine kuvvetle ihtiyaç vardır. Şüphesiz bu görev öncelikle şair ve yazarlara düşmektedir. İşte bu aydın ve sanatkârlar içinde görevini lâyıkı ile yapan gruplardan biri de Büyük Mecmua'da yazan şair ve yazarlardır. 
Bu sanatkârların çoğu, imparatorluğun Birinci Dünya Savaşı'ndan mağlûp çıkmasını ve işgalleri "felaket" veya "facia" olarak nitelendirirler. Yine aynı dönem için bazı sanatkârlar, "gurub" ve onu takiben de "gece" benzetmelerini yaparlar. Milletçe içinde bulunulan elem ve istırap psikolojisini de "matem" kelimesi ile isimlendirirler. Fakat ilânihaye bir aczi ve esareti hiçbiri kabullenmez. Önce kendi moral ve ilgilerini güçlendirmekle işe başlarlar, yani önce kendileri inanırlar, sonra da gençliği ve halkı inandırmak için şiirler ve yazılar yazarlar. Bu işi devletin ve işgalcilerin sansürüne rağmen ellerinden geldiğince yaparlar. İhtişamlı bir tarihe sahip büyük bir millet olduğumuzdan bahisle, böyle şeref ve gururla dolu bir mazinin, meselelerin üstesinden gelip hürriyet ve istiklâle kavuşmada çok önemli bir güç kaynağı olacağını ifade ederler. Büyük Мecmua ve sanatkâr kadrosu olarak, milletin en dinamik kütlesini teşkil eden gençliğe "îman ve mefkûre vermek" lüzumuna inanırlar ve eserlerinde bu fikri de işlerler. Türk tarihinin en kritik bir devresinde, aydın ve sanatkâr sorumluluğuna pek yakışan bu müspet fikir ve sanat faaliyetleriyle onların, Türk Edebiyatı tarihinde itibarlı bir mevkii hak ettiklerini söylemek lâzımdır.

\section{Kaynakça}

Akıncı, T. (2020). İşgal - İstanbul'da Yabancı Güçler. İstanbul:Remzi Kitabevi.

Avni Sadi. (19 Haziran 1919). En Sevgiliye.Büyük Мecmua.(10), 152. İstanbul.

Büyük Mecmua. (2 Teşrîn-i Evvel 1919). (12). İstanbul.

Büyük Mecmua.(30 Teşrîn-i Evvel 1919). (14).İstanbul.

Büyük Mecmua. (13 Teşrîn-i Sânî 1919). (15). İstanbul.

Büyük Mecmua, (11 Kânûn-ı Evvel 1919). (16). İstanbul.

Erişirgil, E.(1986). İslâmcı Bir Şairin Romanı.Ankara:Türkiye İş Bankası Kültür Yayınları

Eroğlu, H. (1982). Türk İnkılâp Tarihi, İstanbul: Millî Eğitim Bakanlığı Yayınları.

Falih Rıfkı. (28 Mayıs 1919).Sevgili İzmir.Büyük Мecmua. (8), 115. İstanbul

Falih Rıfkı. (5 Haziran 1919). Facianın İki Tarafı.Büyük Mecmua. (9), 144. İstanbul.

Falih Rıfkı.(19 Haziran 1919). Faciadan Sonra.Büyük Mecmua, (10), 148. İstanbul.

Faruk Nafiz. (24 Nisan 1919). Hisar'da Akşam.Büyük Местиa, (6), 85. İstanbul.

Faruk Nafiz. (8 Mayıs 1919). Yaralı Arslan.Büyük Mecmua. (7), 103. İstanbul.

Faruk Nafiz. (5 Haziran 1919). Münâcat, Büyük Местиa, (9), 132.İstanbul.

Faruk Nafiz. (5 Haziran 1919). Ey İzmir.Büyük Местиa, (9), 144.İstanbul.

Faruk Nafiz. (19 Haziran 1919). Bugün. Büyük Местиа.(10), 152. İstanbul.

Halide Edip. (5 Haziran 1919). İtilâf Milletlerine.Büyük Mecmua, (9), 13o.İstanbul.

Halide Edip. (16 Teşrîn-i Evvel 1919). Dağa Çıkan Kurt.Büyük Mecmua, (13), 197. İstanbul.

Halide Edip.(25 Kânûn-ı Evvel 1919). Zeynebim Zeynebim.Büyük Mecmua, (17), 262. İstanbul.

İmzasız.(6 Mart 1919). Büyük Mecmua’nın Gayesi.Büyük Mecmua. (1), 1. İstanbul.

İmzasız. (6 Mart 1919). Büyüklerimiz.Büyük Mecmua. (1), 16. İstanbul.

İmzasız. (5 Haziran 1919). İzmir Türk’tür ve Türk Kalacaktır.Büyük Mecmua. (9), 136.İstanbul.

İmzasız. (5 Haziran 1919). Millî Galeyan.Büyük Mecmua.(9), 136. İstanbul.

Kemalettin Kâmi. (5 Haziran 1919). Türk’ün İlâhîsi.Büyük Mecmua.(9), 133.İstanbul.

Köprülüzâde Mehmet Fuat.(6 Mart 1919).Yapma Edebiyat.Büyük Mecmua. (1) 7, İstanbul.

Köprülüzâde Mehmet Fuat. (6 Mart 1919).Firak-ı Irak.Büyük Mecmua, (1), 10. İstanbul.

Adres

Kurklareli Üniversitesi, Fen Edebiyat Fakültesi, Türk Dili ve Edebiyatı Bölümü, Kayalı Kampüsü-Kırklareli/TÜRKİYE e-posta: editor@rumelide.com 
Mehmet Emin.(6 Mart 1919).Tanrıya.Büyük Mecmua, (1)10, İstanbul.

Mehmet Emin. (6 Mart 1919). Millî Ruh.Büyük Mecmua. (1), 11. İstanbul.

Mehmet Emin.(6 Mart 1919). Ümit.Büyük Mecmua. (1), 11. İstanbul.

Mehmet Emin. (6 Mart 1919). Mefkûre.Büyük Mecmua. (1), 11. İstanbul.

M. F. (20 Mart 1919).Şehitlerimize.Büyük Mecmua.(3), 42. İstanbul.

Münir Tevfik. (5 Haziran 1919). Sen Hasta İken.Büyük Mecmua. (9), 115. İstanbul.

M.Z. (20 Mart 1919).Mustafa Kemal Paşa.Büyük Mecmua.(3), 44. İstanbul.

Orhan Seyfi. (5 Haziran 1919).Sancağa.Büyük Mecmua.(9), 132. İstanbul.

Orhan Seyfi. (5 Haziran 1919).Kara Bayrak.Büyük Mecmua.(9), 44. İstanbul.

Orhan Seyfi.(18 Eylül 1919).Annemin Duası.Büyük Mecmua.(11), 174. İstanbul.

Ömer Seyfettin. (13 Mart 1919).Memlekete Mektup.Büyük Mecmua.(2), 30. İstanbul.

Özlük, N. (2010).Büyük Mecmua ve Sistematik İndeksi. Turkish Studies, İnternational Periodical For the Languages, Literature and History of Turkish or Turkic. Volume 5/3 Summer.

Ruşen Eşref. (28 Mayıs 1919).Bıraktığım İstanbul-Bulduğum İstanbul.Büyük Mecmua, (8), 116. İstanbul

Sabiha Zekeriya. (5 Haziran 1919). Son Dua.Büyük Mecmua. (9), 134. İstanbul.

Süleyman Nazif. (6 Mart 1919).Anneme.Büyük Mecmua. (1), 10, İstanbul.

Tansel, S. (1991).Mondros'tan Mudanya'ya Kadar, C.1, İstanbul:Millî Eğitim Bakanlığı Yayınları.

Uzkuç, S. (2005).Büyük Mecmua-Tahlilî Fihrist- İnceleme-Metin (Yüksek Lisans Tezi). Selçuk Üniversitesi Sosyal Bilimler Enstitüsü, Konya.

Yusuf Ziya. (13 Mart 1919). Mefkûre.Büyük Mecmua.(2), 24. İstanbul.

Yusuf Ziya. (Tarihsiz). Ölü Evinde Düğün.Büyük Mecmua, (4), 56. İstanbul.

Yusuf Ziya. (Tarihsiz). İstanbul.Büyük Mecmua.(5), 7o. İstanbul.

Yusuf Ziya.(24 Nisan 1919). Bahar.Büyük Mecmua.(6), 85. İstanbul.

Yusuf Ziya. (8 Mayıs 1919). Guruba Doğru.Büyük Мecmua, (7), 103. İstanbul.

Yusuf Ziya. (28 Mayıs 1919).Günah.Büyük Mecmua.(8), 116. İstanbul.

Yusuf Ziya.(5 Haziran 1919). Eğil Dağlar Eğil.Büyük Mecmua.(9), 136.İstanbul.

Yusuf Ziya. (5 Haziran 1919). Ramazan Gecesi.Büyük Mecmua.(9), 13. İstanbul.^ 